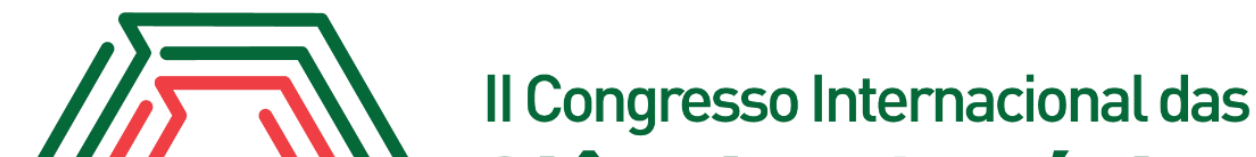 Ciências Agrárias COINTER - PDVAgro 2017
}

\section{INDICE RELATIVO DE CLOROFILA EM PEPINEIRO FERTIGADO COM SOLUÇÕES NUTRITIVAS SALINAS E ENRIQUECIDAS COM POTÁSSIO}

\author{
Apresentação: Pôster
}

Paulo Victor de Menezes ${ }^{1}$; Jessilanne Plínia Barbosa de Medeiros Costa²; Isabelly Cristina da Silva Marques $^{3}$; Francisco Adênio Teixeira Alves ${ }^{4}$; Francisco de Assis de Oliveira ${ }^{5}$

\section{Introdução}

O pepineiro destaca-se entre as hortaliças de fruto mais produzidas e consumidas no Brasil, sendo bastante cultivada em ambiente protegido, sistema este que apresenta grandes benefícios, principalmente para os pequenos e médios produtores, pelo cultivo intensivo e alta produtividade (CANIZARES et al., 2004).

Atualmente vem crescendo consideravelmente no Brasil, especialmente em sistema protegido, o cultivo de plantas sem solo, buscando a otimização no uso da água, do espaço, do tempo, dos nutrientes e da mão-de-obra. No cultivo sem solo, o uso de substrato inerte acondicionado em recipientes tem ganhado destaque, principalmente no cultivo de hortaliças de fruto, como o pepineiro.

A cultura do pepineiro é considerada moderadamente sensível à salinidade, apresentando salinidade limiar de 2,2 dS m${ }^{-1}$ (AYERS \& WESTCOT, 1999), no entanto, estudos já mostraram que as plantas cultivadas em substratos inertes apresentam maior tolerância à salinidade (SOARES et al., 2007). No entanto, mesmo neste sistema de cultivo deve-se dar atenção à qualidade da água utilizada no preparo da solução nutritiva, pois, o excesso de sais geralmente acarreta em redução no teor de clorofila.

Desta forma, o uso de água salina deve ser realizado com cautela, mediante a adoção de manejo cultural que minimizem o efeito do efeito salino sobre as plantas. Neste contexto, o manejo

\footnotetext{
${ }^{1}$ Graduando em Agronomia, Universidade Federal Rural do Semi-Árido, paulo escoteiro39@hotmail.com

${ }^{2}$ Mestranda PPGMSA/UFERSA, Universidade Federal Rural do Semi-Árido, jessilannyplinia@hotmail.com

${ }^{3}$ Engenheira Agrônoma, Universidade Federal Rural do Semi-Árido, isabelly cristinna@hotmail.com

${ }^{4}$ Graduando em Agronomia, Universidade Federal Rural do Semi-Árido, adenio.a@hotmail.com

${ }^{5}$ Prof. Doutor, Universidade Federal Rural do Semi-Árido, thikaoamigao@ufersa.edu.br
} 
nutricional da aplicação de potássio extra na solução é interessante, pois este nutriente desempenha funções importantes, em processos osmóticos, na síntese de proteínas e na manutenção de sua estabilidade, na abertura e fechamento dos estômatos e na permeabilidade da membrana (MALAVOLTA, 2006).

Diante do exposto, o presente trabalho foi desenvolvido com o objetivo de avaliar o efeito de soluções nutritivas salinas e enriquecidas com potássio sobre o índice relativo de clorofila em dois híbridos de pepineiro.

\section{Fundamentação Teórica}

O sistema hidropônico predominante na produção de hortaliças em ambiente protegido é o NFT, no entanto, atualmente o cultivo de hortaliças utilizando substratos inertes quimicamente vem se expandindo nas diferentes regiões do Brasil, pois, o emprego de substratos para o cultivo hidropônico de hortaliças folhosas pode simplificar tanto o manejo da fertirrigação como os controles da solução nutritiva e, ainda, diminuir o consumo de energia elétrica.

Independente do sistema de cultivo utilizado, o sucesso do cultivo hidropônico está diretamente relacionado à solução nutritiva, atentando para o cálculo, o preparo e manejo, pois é ela quem determina o crescimento das plantas e a qualidade do produto final, principalmente quanto à condutividade elétrica da solução nutritiva (ANDRIOLO et al., 2009).

A quantificação da clorofila é relevante no estudo de práticas culturais e de manejo visando aumentar o potencial fotossintético e rendimento das espécies, pois, de acordo com Taiz \& Zeiger (2009), o conteúdo de clorofilas nas folhas é influenciado por diversos fatores bióticos e abióticos, estando diretamente relacionado com o potencial de atividade fotossintética das plantas.

Em plantas submetidas à salinidade os decréscimos na concentração de clorofila podem ser atribuídos ao aumento da atividade da enzima clorofilase que degrada a clorofila (SHARMA \& HALL, 1991).

A tolerância à salinidade é variável entre espécies e, mesmo em uma espécie, entre estádios de desenvolvimento, em cada fase a tolerância à salinidade é controlada por mais de um gene e altamente influenciada por fatores ambientais (MUNNS, 2005). Além de reduzir o crescimento, reduz o conteúdo de clorofila em plantas sensíveis e aumenta em plantas tolerantes a salinidade (MUNNS, 1993). 


\section{Metodologia}

O experimento foi realizado entre os meses de agosto e setembro de 2017, em casa de vegetação, no setor experimental do Departamento de Ciências Ambientais e Tecnológicas, da Universidade Federal Rural do Semi-Árido (UFERSA), Campus Oeste, Mossoró-RN.

Utilizou-se o delineamento em blocos casualizados, com cinco tratamentos e três repetições, sendo cada repetição foi formada por 3 vasos plásticos com capacidade para $10 \mathrm{~L}$, contendo uma planta cultivada em substrato de fibra de coco. Os tratamentos foram constituídos por cinco soluções nutritivas ( $\mathrm{S} 1$ - solução nutritiva padrão; $\mathrm{S} 2$ - solução padrão salinizada $\left(3,5 \mathrm{dS} \mathrm{m}^{-1}\right)$; $\mathrm{S} 3$ $\mathrm{S} 2+50 \%$ de K; S4 - S2 + 100\% de K).

A solução nutritiva padrão seguiu a recomendação de Furlani et al. (1999), contendo a seguinte quantidade de fertilizantes, em gramas para 300L: 165,3; 74,1; 92,5; 357,8 e 177,8g, de N$\mathrm{KNO}_{3}$; P-MAP; K-KCl; $\mathrm{Ca}-\mathrm{CaNO}_{3}$ e $\mathrm{MgMgSO}$, respectivamente. Como fonte de micronutrientes utilizou-se um composto comercial. $\mathrm{O} \mathrm{pH}$ das soluções nutritivas em todos os tratamentos foi monitorado e ajustado à faixa de 5,5 a 6,5 utilizando-se $\mathrm{HCl}$ ou $\mathrm{NaOH}$.

O índice relativo de clorofila (IRC) foi mensurado utilizando um clorofilômetro portátil (CCM200-Plus), realizando-se três medidas em cada planta.

Os dados obtidos foram submetidos à análise de variância, as médias foram comparadas pelo teste Tukey a 5\% de probabilidade. Análises estatísticas foram realizadas utilizando o programa de estatística SISVAR (FERREIRA, 2011).

\section{Resultados e Discussões}

As soluções nutritivas utilizadas afetaram o índice relativo de clorofila (IRC) de forma diferente de acordo com o hibrido de pepino estudado. Para o híbrido Nagai Japonês, o uso de solução nutritiva salinizada não afetou significativamente o IRC, no entanto, ao aplicar solução nutritiva salinizada e enriquecida com K em $100 \%$ da concentração recomendada houve aumento significativo no IRC, ocorrendo aumento de 19, 22 e 35\% em comparação com os teores obtidos nas soluções S1, S2 e S3, respectivamente (Figura 1A).

Para o híbrido Targa verificou-se que não também não houve efeito significativa do uso de solução nutritiva salinizada com $\mathrm{NaCl}$, no entanto, quando utilizou-se solução nutritiva enriquecida 
com K em $100 \%$ houve redução no IRC, ocorrendo redução de $27,2 \%$ em comparação ao IRC observado na solução nutritiva padrão (Figura 1B).

Figura 1. Índice relativo de clorofila em dois híbridos de pepino (A - Nagai Japonês; B - Targa) cultivados em fibra de coco e fertigados com soluções nutritivas salinas enriquecidas com potássio (Médias com a mesma letra não diferem estatisticamente pelo teste de Tukey a 5\% de probabilidade)

A.

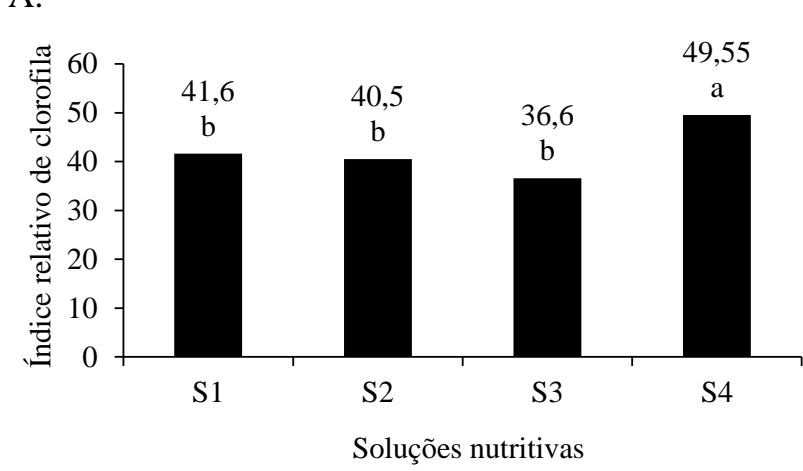

B.

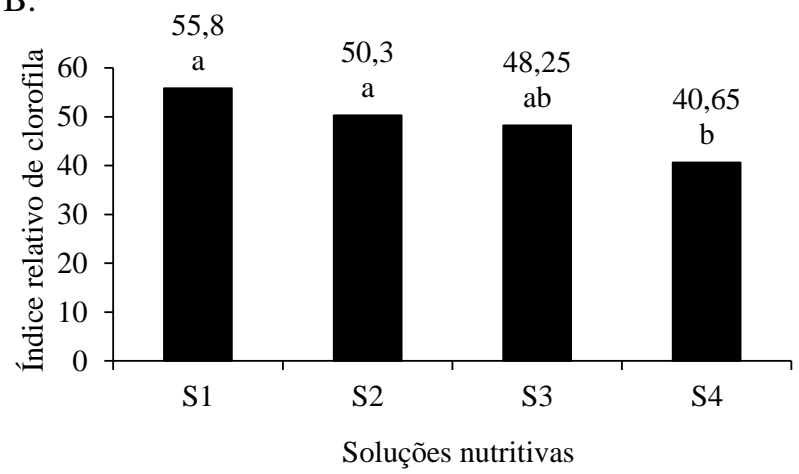

De forma geral, verifica-se que apenas a solução nutritiva S5 diferiu das demais para ambos os híbridos de pepino. Considerando que não haver correlação direta entre níveis de potássio e síntese de clorofila (PETTER et al., 2016), o efeito da elevada concentração de potássio sobre o IRC pode ser atribuído ao efeito indireto, produzido pelo aumento da condutividade elétrica da solução nutritiva.

A diferença na resposta dos híbridos observada no presente trabalho pode ser um indicativo que os genótipos estudados diferem quanto à tolerância à salinidade, pois, de acordo com Munns (1993), que o teor de clorofila aumenta com os níveis de salinidade em espécies tolerantes e diminui em espécies sensíveis.

Resposta diferente de genótipos de pepino à salinidade quanto ao teor de clorofila também foi observada por Sarwar et al. (2017) trabalhando com diferentes genótipos de pepino, assim como por Aragão et al. (2009) trabalhando com estresse salino em cultivares de meloeiro, os quais verificaram que que houve redução nos teores de clorofila para todas as cultivares com o aumento da salinidade dos solos, no entanto, esses observaram que o grau de resposta diferiu entre as cultivares utilizadas. 


\section{Conclusões}

Os híbridos diferem quanto a tolerância à salinidade no tocante ao índice relativo de clorofila. O uso de solução nutritiva salinizada e enriquecida com 100\% de K aumentou o IRC no híbrido Nagai Japonês, mas reduziu no híbrido Targa.

\section{Referências}

ANDRIOLO, J. L.; JANISCH, D. I.; SHIMITT, O. J.; VAZ, M. A. B.; CARDOSO, F. L.; ERPEN, L. Concentração da solução nutritiva no crescimento da planta, na produção e na qualidade de frutas do morangueiro. Ciência Rural. v.39, n.3, p.684-690, 2009.

ARAGÃO, C.A.; SANTOS, J.J.; QUEIROZ, S.O.P.; DANTAS, B.F. Avaliação de cultivares de melão sob condições de estresse salino. Revista Caatinga, v.22, n.2, p.161-169, 2009.

AYERS, R. S.; WESTCOT, D. W. A qualidade da água na agricultura. 2.ed. Campina Grande: UFPB, 1999. 153p. FAO. Estudos de Irrigação e Drenagem, 29 revisado.

CANIZARES, K. A. L.; RODRIGUES, J. D.; GOTO, R. Crescimento e índices de troca gasosa em plantas de pepino irrigadas com água enriquecida com $\mathrm{CO}_{2}$. Horticultura Brasileira, Brasília, v.22, n.4, p.706-711, 2004.

FERREIRA, D. F. Sisvar: a computer statistical analysis system. Ciência \& Agrotecnologia, 35(6), 1039-1042, 2011.

FURLANI, P. R.; BOLONHEZI, D.; SILVEIRA, L. C. P.; FAQUIN, V. Nutrição mineral de hortaliças, preparo e manejo de soluções nutritivas. Informe Agropecuário, Belo Horizonte, v. 20, n. 200-201, p. 90-98, 1999.

MALAVOlTA, E. Manual de nutrição mineral de plantas. São Paulo: Editora Agronômica Ceres, 638p. 2006.

MUNNS, R. Genes and salt tolerance: Bring them together. New Phytologist, v.143, p.645-663, 2005.

MUNNS, R. Physiological processes limiting plant growth in saline soil: some dogmas and hypothese. Plant, Cell and Environment, Oxford, v.16, n.1, p.15-24, 1993.

PETTER, F. A.; ANDRADE, F. R.; ZUFFO, A. M.; MONTEIRO, M. M. S.; PACHECO, L. P.; ALMEIDA, F. A. Doses e épocas de aplicação de potássio no desempenho agronômico do milho no cerrado piauiense. Comunicata Scientiae, v.7, n.3, p.372-382, 2016.

SARWAR, M.; AMJAD, M.; AYYUB, C. M. Alleviation of salt stress in cucumber (Cucumis sativus) through seed priming with triacontanol. International Journal f oAgriculture \& Biology, v.19, n.4, p.771-778, 2017.

SHARMA, P. K.; HALL, D. O. Interaction of salt stress and photoinhibition on photosynthesis in barley and sorghun. Journal of Plant Physiology, v.138, n.5, p.614-619, 1991.

SOARES, T. M.; SILVA, E. F. F.; DUARTE, S. N.; MELO, R. F.; JORGE, C. A.; BONFIMSILVA, E. M. Produção de alface utilizando águas salinas em sistema hidropônico. Irriga, v.12, n.2, p.235-248, 2007.

TAIZ, L.; ZEIGER, E. Plant physiology. 3.ed. Porto Alegre: Artmed, 2009. 719p. 